\title{
A Scanning Electron Microscopic Study of the Intercalated Portion of the Biliary System in the Rat Liver*
}

\author{
Hiromi Takahashi-Iwanaga and Tsuneo Fujita \\ Department of Anatomy, Niigata University School of Medicine, Niigata, Japan
}

Received August 22, 1991

\begin{abstract}
Summary. The intercalated portion of the rat liver was studied by scanning electron microscopy (SEM) after removal of interlobular connective tissue by acid or alkaline hydrolysis. Biliary intercalated portions have generally been regarded as short straight links lying between the bile capillary network and the interlobular duct. The biliary system as observed by SEM lacked such specialized segments for linking. Instead, it contained long intercalated ductules taking winding and branching courses. The ductular branches frequently anastomosed with each other to form an extensive plexus along the limiting plate. The ductules repeatedly connected with the plate on their courses as well as at their terminals. This disposition of the ductules probably potentiates their tolerance to luminal obstruction. At the junction between the ductule and the limiting plate, ductular cells and hepatocytes shared the biliary lumen. The lumen sometimes approached the base of the ductule, providing a possible route for bile leakage.

The intercalated ductule was composed of low fusiform epithelial cells throughout its length, meeting its classical criteria by light microscopy. Its basal surface was furrowed with narrow grooves along cell boundaries. The ductular cells extended numerous microplicae in the basal grooves and on their lateral surfaces, suggesting their secretory function.
\end{abstract}

The structure of peripheral branches of bile ducts has not been fully clarified as yet. Observation in thin tissue sections is insufficient for visualizing their winding courses and their relation to the bile capillaries, which also form complex networks. HERING (1867), who studied biliary passages in the liver by retrograde injection of Berlin blue into the common bile duct, depicted a short straight canal as linking the intralobular network of bile capillaries to the interlobular duct (Fig. 7 in HERING, 1867). This canal has since been known by his name and generally regarded as an intercalated portion in the biliary system. In many textbooks of histology, the Hering's canal has been described as a short simple twig arising from a thick ductal tree, with bile capillaries converging at its terminal (PRENANT and BOUIN, 1911; SMith and Copenhaver, 1948; STÖHR et al., 1959; HAM and LEESON, 1961; BARGMANN, 1962; Williams and WARWICK, 1980; FuJiTA and Fujita, 1984; JONES and SPRING-MiLlS, 1988).

Several investigators, however, questioned the existence of such short intercalated ductules (LETULLE, 1915). By the Rio Hortega silver carbonate staining method, MCINDOE (1928) suggested that what had been called the Hering's canal did not represent an actual canal but corresponded to a focal distension of a bile capillary frequently occurring near its junction with a ductular terminal.

On the other hand, ClARA (1930), who examined liver sections stained by iron-hematoxylin, described "Zwischenstücke" or intercalated portions as thin long passages resembling those in the pancreas (ZIMMERMANN, 1927). The biliary intercalated ductules observed by CLARA were lined by a simple squamous epithelium which was composed of clear cells with oval nuclei extended longitudinally. The ductules were often bifurcated, connecting with bile capillaries at their terminals as well as on their lateral walls.

ELIAS (1949) traced intrahepatic biliary passages with indigo carmine, which was injected intravenously and then excreted into bile. He supported the findings by CLARA, in that the biliary intercalated ductule was characterized by its small diameter and low clear epithelium. However, ELIAS assumed that the intercalated ductules were much longer than CLARA had conceived, forming an extensive plexus devoid of free

\footnotetext{
*This study was supported by a grant from the Ministry of Education, Science and Culture, Japan (No. 03770007).
} 
terminals. In fact, bile capillaries always open on their lateral walls (ELIAS and SHERRICK, 1969). According to ELIAS, the interlobular space was lined by a wall of hepatocytes, which he referred to as a limiting plate. The limiting plate contained a twodimensional network of bile capillaries, through which bile secreted in the hepatic lobule was drained into the plexus of intercalated ductules.

Recently, MURAKAMI et al. (1984) successfuily demonstrated the biliary excretory system in the rat liver by SEM, casting its lumen with low-viscosity resin. In their study, small branches of interlobular ducts anastomosed with each other to form a plexus resembling that proposed by ELIAS. However, the ductal plexus observed by MURAKAMI et al. extended short ductules, which they identified as the canals of Hering. The canals penetrated the limiting plate and communicated with the bile capillaries at their terminals.

The present study aims to clarify the threedimensional structure of intercalated ductules in the biliary system and their relation to the hepatic parenchyma, filling the information gaps in previous reports. Hepatic plates and bile ductules in the rat liver are exposed after hydrolytic removal of interlobular connective tissue, to be examined by scanning electron microscopy (SEM).

\section{MATERIALS AND METHODS}

Adult male Wistar rats weighing $180-220 \mathrm{~g}$ were examined in this study. All animals were anesthetized with sodium pentobarbital and perfused through the ascending aorta with Lock's solution, and subsequently, with $2.5 \%$ glutaraldehyde in $0.1 \mathrm{M}$ phosphate buffer, $\mathrm{pH}$ 7.3. The liver was excised, cut into small cubes, about $2 \mathrm{~mm}$ on each side, and immersed in the same fixative for $3 \mathrm{~h}$ or more at room temperature. After fixation, some tissue blocks were treated by a modification of the method by EVAN et al. (1976), while others were processed by the $\mathrm{NaOH}$ maceration method originated by us (TAKAHASHI-IWANAGA and FUJITA, 1986). In the former method, specimens were placed in $8 \mathrm{~N} \mathrm{HCl}$ for about $60 \mathrm{~min}$ at $60^{\circ} \mathrm{C}$, transferred to $0.05 \%$ Tween 20 in phosphate buffer, and then exposed to ultrasonic vibrations for 1-2 min to remove connective tissue cells and fine vessels. In the latter, the tissue pieces were treated with $6 \mathrm{~N}$ $\mathrm{NaOH}$ for $25 \mathrm{~min}$ at $60^{\circ} \mathrm{C}$. In either method, the hydrolyzed tissue blocks were rinsed in $0.01 \mathrm{M}$ phos-

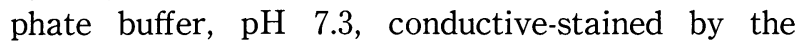
tannin-osmium method by MURAKAMI (1974), dehydrated in a graded series of ethanol, transferred to isoamyl acetate, and critical point-dried using liquid $\mathrm{CO}_{2}$. The dried specimens were evaporation-coated with gold-palladium and examined in a Hitachi S-450 LB scanning electron microscope at an accelerating voltage of $10 \mathrm{kV}$.

\section{RESULTS}

Both $\mathrm{HCl}$ digestion and $\mathrm{NaOH}$ maceration removed all connective tissue elements in the interlobular spaces in the liver, exposing the basal surface of the limiting plate (ELIAS, 1949) and long intercalated ductules. The former treatment was effective in pursuing the courses of the ductules and their relation to the limiting plate, as it conserved junctions between epithelial cells. On the other hand, the latter often evoked cell dissociation, revealing the luminal and lateral surfaces of hepatocytes in the limiting plate and those of ductular cells. The two methods, complementing each other, allowed us to visualize the cytoarchitecture of the limiting plate and the intercalated ductules.

The limiting plate measured $5-10 \mu \mathrm{m}$ in thickness, half the thickness of intralobular hepatic plates. Hepatocytes in the limiting plate exposed large polygonal facets, measuring $20-30 \mu \mathrm{m}$ in size to the interlobular space. The cellular facets were provided with numerous microvilli ranging between 0.3 and $1.0 \mu \mathrm{m}$ in length and narrow winding grooves corresponding to the impressions of collagen fibers. The limiting plate was perforated by large elongated lacunae measuring about $8 \mu \mathrm{m}$ in width and small round pores measuring about $1 \mu \mathrm{m}$ in diameter (Fig. 1). The former corresponded to the entrances of blood vessels passing into the hepatic lobule, while the latter contained collagen fibers.

The intercalated ductules were long canals measuring $100-600 \mu \mathrm{m}$ in length and $8-10 \mu \mathrm{m}$ in thickness (Fig. 2a). They were composed of fusiform epithelial cells elongated in the long axis of the ductule (Fig. $2 b$, c). On the basal aspect of the ductule, deep furrows coursed along the cell boundaries. Ductular cells showed smooth basal surfaces with sparse short microplicae, resembling flaps. The microplicae occurred rather densely in the intercellular furrows. On their lateral aspect, the ductular cells displayed dense microplicae in the basal half of their height. Most of the lateral microplicae were oriented parallel to the basal cell ridges. Adjacent cells tightly interdigitated with each other by the microplicae. The luminal surfaces of the ductular cells were covered with stubby microvilli, occasionally extending a single cilium.

The intercalated ductules bifurcated or trifurcated 

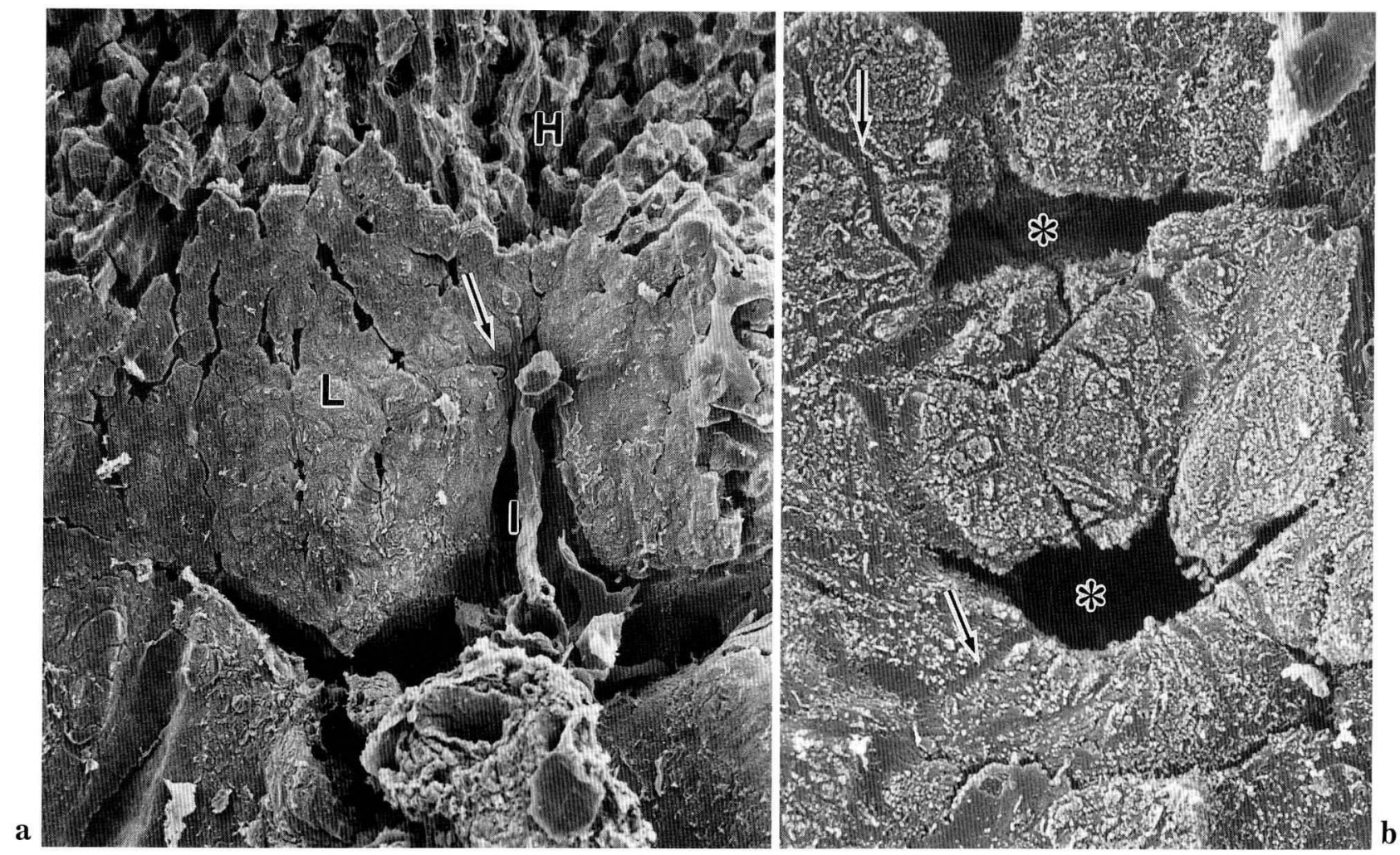

Fig. 1 a. Low magnification view of a peripheral region of a rat hepatic lobule. The lobule $(H)$ is bounded by a limiting plate $(L)$, i.e., a continuous layer of hepatocytes. An intercalated bile ductule $(I)$ is connected with the limiting plate $($ arrow). $\times 330$. b. High magnification of the basal surface of a limiting plate. Hepatocytes are covered with short microvilli. Asterisks indicate entrances for blood capillaries pouring into a hepatic lobule. Arrows impressions by collagen fibers. $\times 1,600$. a, b: $\mathrm{HCl}$ digestion method.

every $30-60 \mu \mathrm{m}$, spreading along the limiting plate. Some branches terminated in free ends, while others anastomosed with each other to form a loop (Fig. 3). In some cases, the ductules repeated branchings and anastomoses, resulting in a large network (Fig. 4). Each branch of the bile ductules was connected with the limiting plate at its terminal. In addition, the ductules repeatedly contacted the plate with the base of their epithelium.

At the junction between the intercalated ductule and the limiting plate, the ductular cells became attenuated and intimately attached to the plate (Fig. $3 \mathrm{~b})$. On the basal aspect, the neighboring ductular cells and hepatocytes revealed fine interdigitations. The basal surfaces of the former were smooth, in marked contrast to those of the latter covered with microvilli. No intermediate cells were found between the two types of cells.

At places where an intercalated ductule was detached from the limiting plate, the latter revealed smooth contacting facets furrowed with a central groove which was covered by short columnar microvilli (Fig. 5). The groove, together with its counterpart in the ductular cells, bounded a complete biliary lumen. The groove measured $2-3 \mu \mathrm{m}$ in width and varied in length from 8 to $30 \mu \mathrm{m}$. It extended along the cell boundaries of hepatocytes, taking a simple straight course or more complex L- or Y-shaped one. Two or three bile capillaries opened at the ends or bends of the groove through round orifices with a diameter of about $1 \mu \mathrm{m}$. In some places, the groove extended short narrow branches, each of which was lined by a hepatocyte and an apposing ductular cell; an intercellular canaliculus was formed in this way. The intercellular canaliculus often approached the basal surface of the ductular epithelium, leaving a short distance no more than $0.5 \mu \mathrm{m}$.

Some ductular cells could be recognized within a hepatic lobule. The intralobular ductular cells were surrounded by hepatocytes but could be differentiated by their smooth basal surfaces. An intercalated ductule occasionally penetrated the hepatic lobule for 


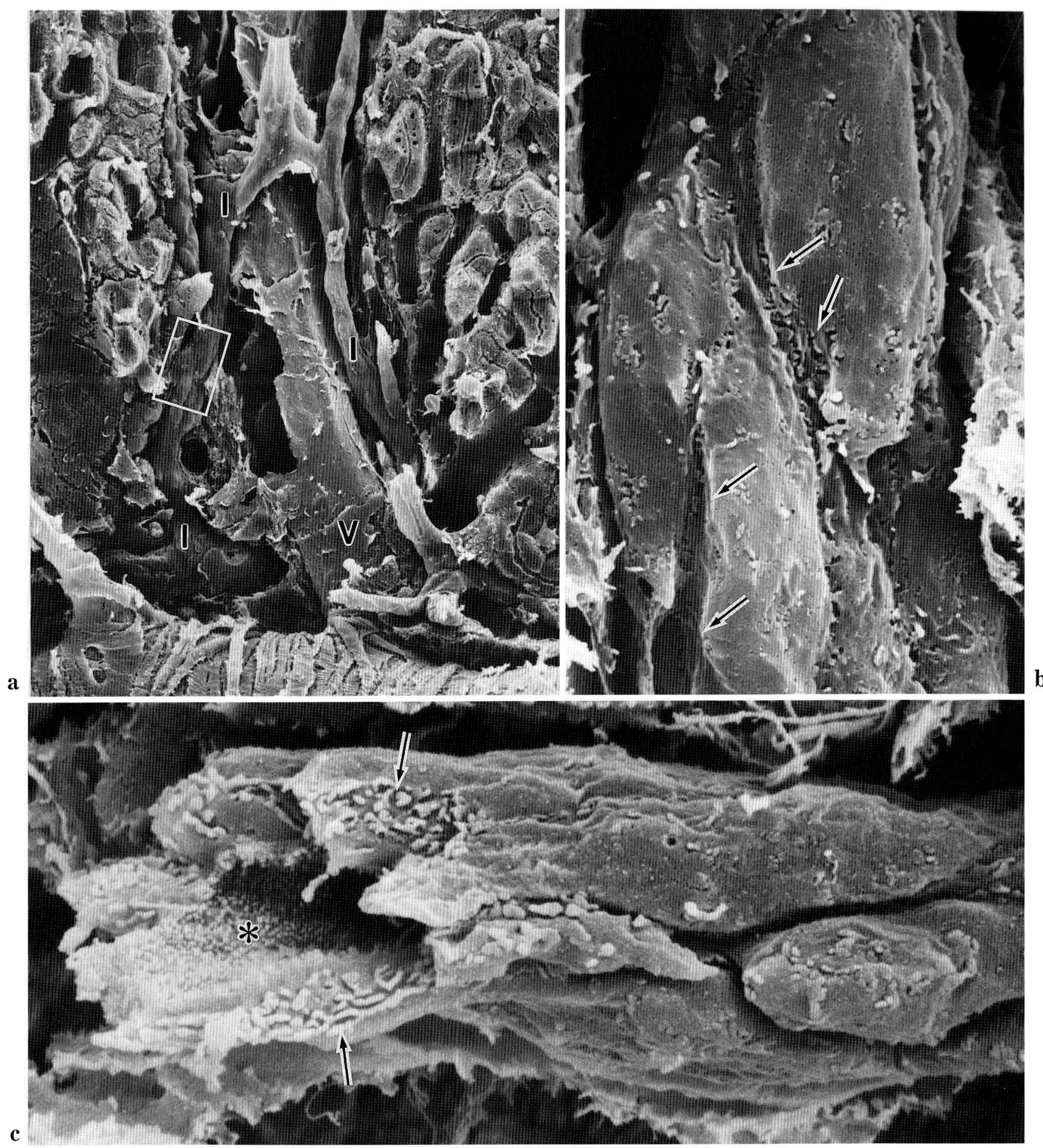

Fig. 2 a. A portal vein branch $(V)$ surrounded by a plexus of intercalated ductules $(I)$. $\times 580$. b. High magnification of the rectangle in Figure 2 a showing smooth basal surfaces of ductular epithelial cells. Deep grooves extend along cell boundaries (arrows). $\times 6,000$. c. An intercalated ductule fractured transversely. Its luminal surface is covered with stubby microvilli (asterisk). Note dense microplicae on the basal half of its lateral surface (arrows). $\times 4,500$. a-c: $\mathrm{NaOH}$ maceration method. 

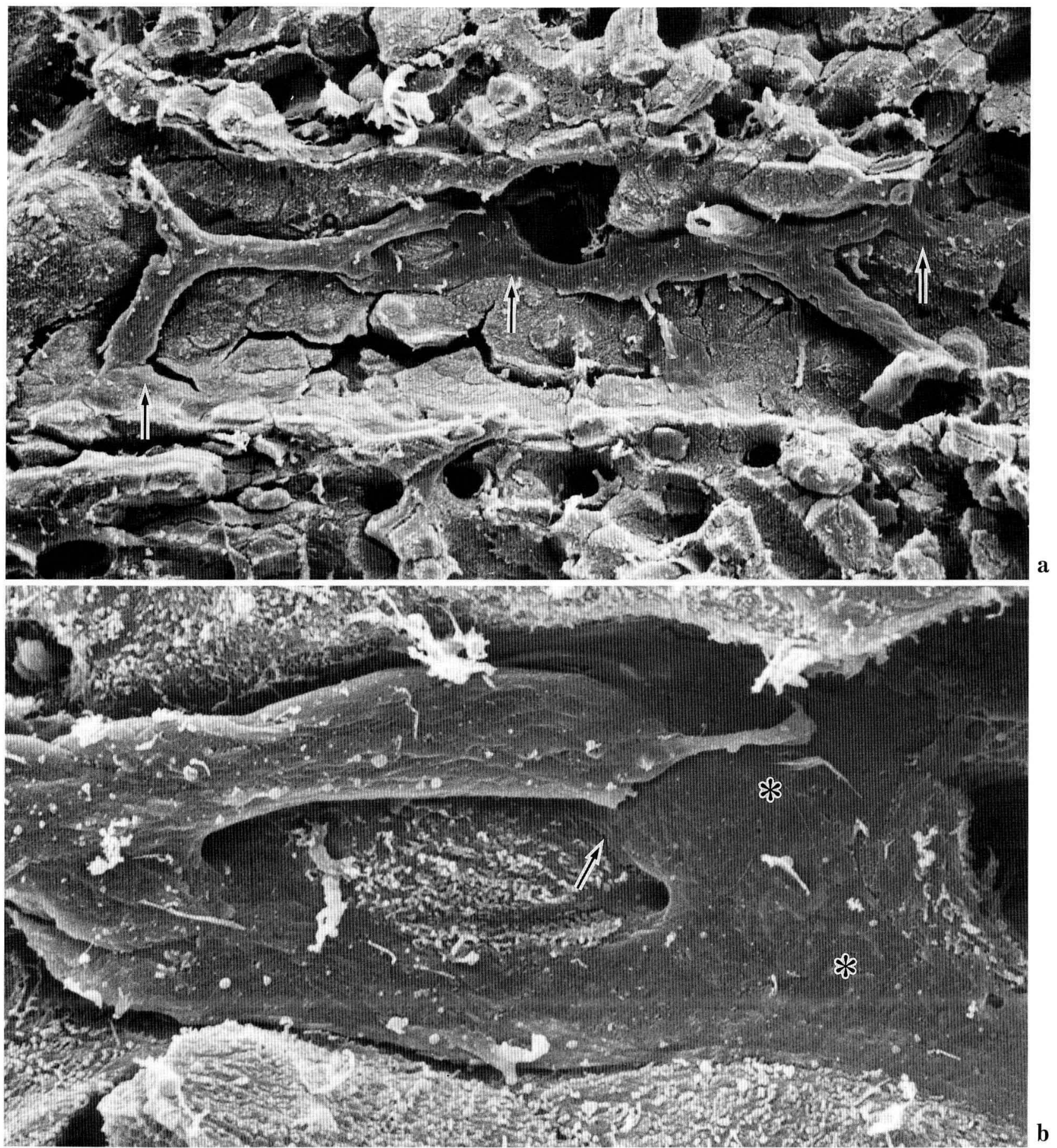

Fig. 3 a. An intercalated ductule with bifurcations and a trifurcation. At the center of the photograph, some of its branches anastomose, forming a loop. Arrows indicate junctions between the ductule and a limiting plate. $\times 770$. b. High magnification of the central area in Figure $3 \mathrm{a}$. Attenuated ductular cells (asterisks) are closely attached to the limiting plate. Arrow indicates interdigitation between a ductular cell and a hepatocyte. $\times 2,700$. a, b: $\mathrm{HCl}$ digestion method. 


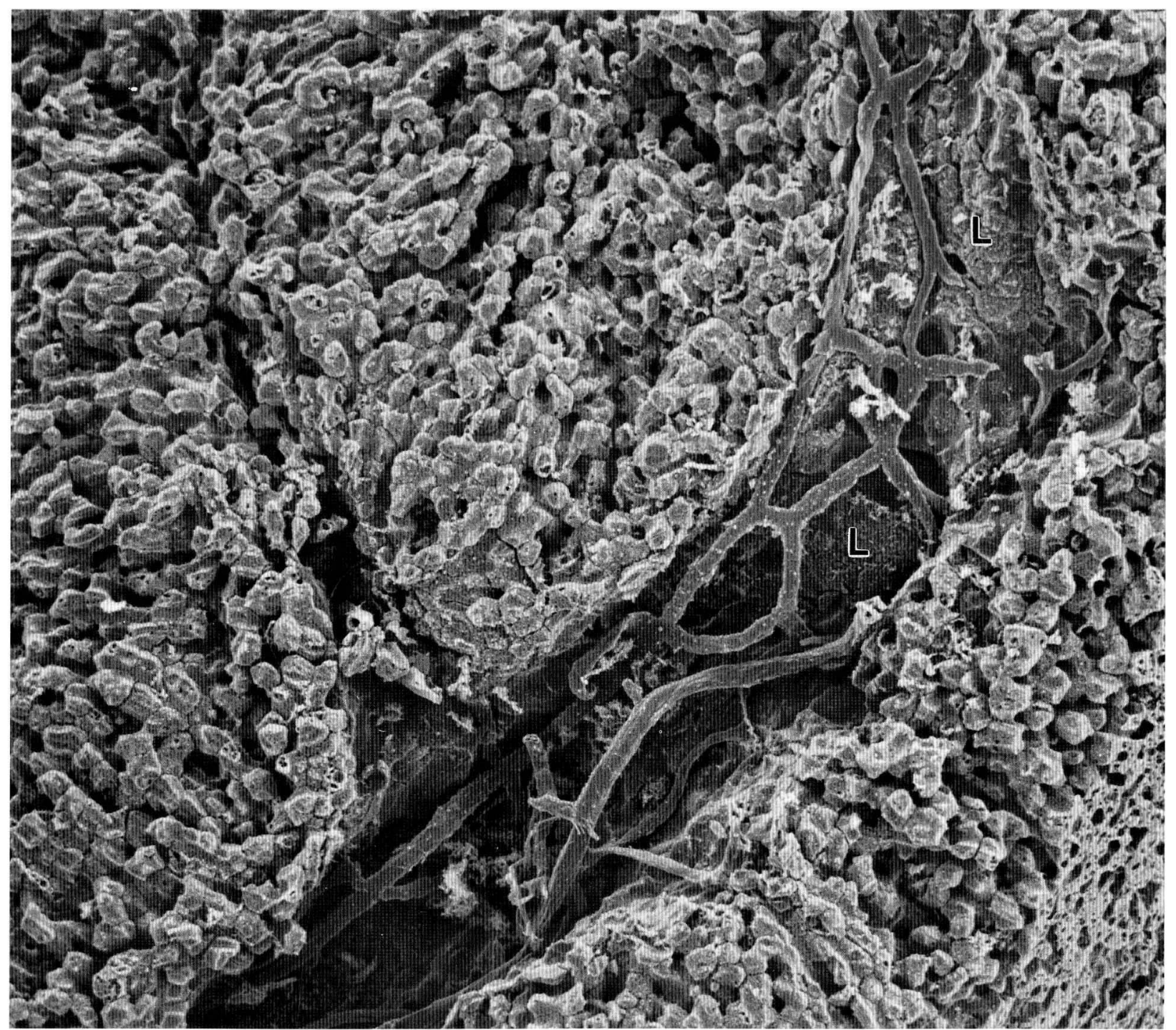

Fig. 4. A plexus of intercalated ductules. The ductules repeatedly branch and anastomose, extending along a limiting plate $(L) . \mathrm{HCl}$ digestion method. $\times 260$

a short distance through a vascular lacuna within it. The ductule, in such a case, was closely associated with the intralobular hepatic plates and terminated with an attenuated end (Fig. 6a, b). Solitary ductular cells devoid of connection with any ductular terminals were found more frequently in the lobule. The cells were dispersed in the limiting plate, exposing their small basal facet, wedge-like in shape (Fig. 6c, d).

\section{DISCUSSION}

The present SEM observation demonstrated that the biliary intercalated portion, at least in the rat, is a complex ductular plexus extending along the limiting plate. Some intercalated ductules branched in a dichotomical fashion in accord with the findings by ClARA (1930), while others frequently anastomosed with each other to form a network, as described by ELIAS and SHERRICK (1969). In both cases, the intercalated ductules observed by SEM extended much farther than those shown in previous studies.

Based on his dye-injection study, HERING (1867) described short straight passages, which later came to be called Hering's canals, as linking the bile capillaries with the interlobular bile ductule. According to his description, the ductule formed a wide-meshed plexus enclosing a portal vein branch. His ductular 

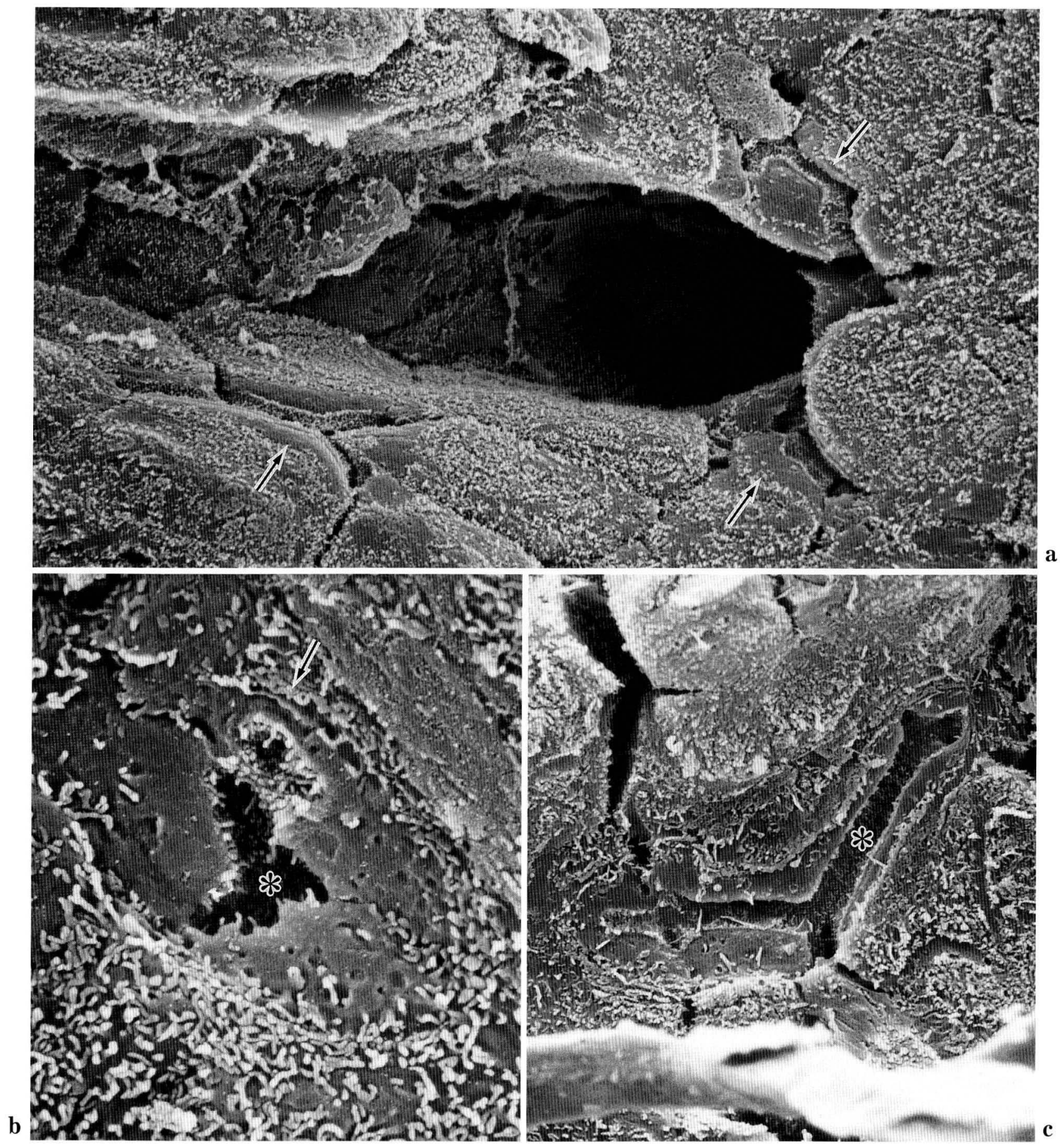

Fig. 5. Limiting plates showing small smooth zones which have been in contact with intercalated ductules. a. A limiting plate displaying such contacting areas of varying shapes (arrows). $\times 2,200$. b. High magnification of a round contacting area. The biliary lumen (asterisk) is densely covered with cylindrical microvilli. An intercellular canaliculus approaches the ductular base (arrow). $\times 5,700$. c. A limiting plate showing an L-shaped contacting facet. Asterisk biliary lumen. $\times 2,400$. a-c: $\mathrm{NaOH}$ maceration method. 
plexus has generally been forgotten although it appeared in the textbook by MAXIMOW and BLOOM (1935) and in a review by WALLRAFF (1969). Recently, MURAKAMI et al. (1984) corroborated its existence by SEM, casting the biliary lumina in rat liver. Previous investigators subsequent to Hering conceived that short connecting canals must be intercalated between the ductular plexus and the bile capillary network (MAXIMOW and BloOM, 1935; WALlRAFF, 1969; MurAKAMI et al., 1984). However, the present SEM study
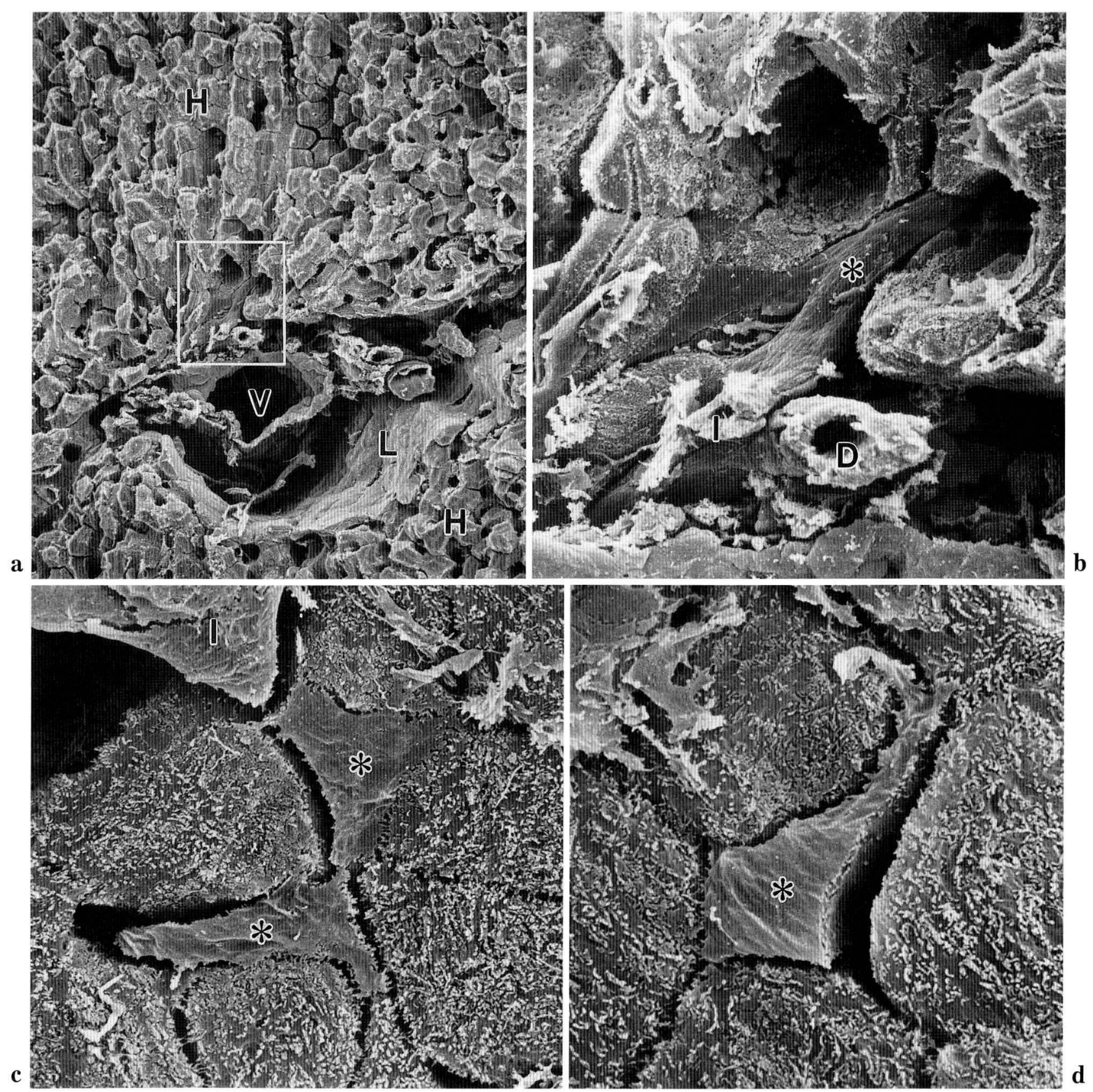

Fig. 6 a. Low magnification view of a periportal area. $H$ hepatic lobules, $L$ limiting plate, $V$ portal vein branch. $\times 260$. b. High magnification of the rectangle in Figure 6 a. A branch of an intercalated ductule $(I)$ enter the hepatic lobule (asterisk). $D$ interlobular duct. $\times 1,000$. c. Ductular cells dispersed into a limiting plate (asterisks). I terminal of an intercalated ductule. $\times 1,800$. d. A solitary ductular cell (asterisk) in a limiting plate. $\times 2,400$. a, b: $\mathrm{HCl}$ digestion method; c, d: $\mathrm{NaOH}$ maceration method. 
indicates that the biliary intercalated portion does not correspond to the short connecting passage but to the entire plexus of interlobular ductules correctly depicted but erroneously identified by HERING (1867) and by MuraKami et al. (1984). The authors are of the opinion that what has been called the Hering's canal does not represent any specialized segment in the biliary excretory system.

Physiological studies have shown that intrahepatic bile ducts are involved in the modification of canalicular bile derived from hepatocytes by absorbing or secreting water and solutes, although the site of this task has not yet been localized in the biliary tree (ERLINGER and DHUMEAUX, 1974). The present study suggests that the intercalated portion might play a certain role in modifying bile, as it revealed an extraordinarily long course under the SEM.

STEINER and CARRUTHERS (1961), who studied the biliary passages in various mammalian species by transmission electron microscopy, described the epithelial cells in bile pre-ductules or intercalated ductules as displaying complex plications of lateral cell membranes. STERNLIEB (1972) reported that the bile ductules in human livers formed intercellular lacunae bordered by overlapping cytoplasmic projections. STERNLIEB assumed that the intercellular lacunae were involved in fluid transport in ductular epithelia, as similar structures had been found during active absorption by epithelial cells of the gallbladder (YAMADA, 1955; KAYE et al., 1966). The present SEM observation confirmed the previous TEM findings, demonstrating marked amplification of the lateral cell membrane of ductular cells due to dense microplicae.

ELIAS (1949) showed that hepatocytes in the most peripherial region of the lobule formed a continuous cell plate, a "limiting plate", which separated the hepatic parenchyma from the interlobular connective tissue. He thought that the network of bile capillaries in the limiting plate provided a draining passage for bile from the hepatic lobule to the interlobular bile ducts. Using an SEM, MоTTA and his colleagues showed freeze-cracked surfaces of the limiting plate and its junctions with bile ductules, supporting the findings by Elias (MotTA et al., 1978; MotTA, 1984). By removing the interlobular connective tissue, the present study could further demonstrate the topography of the limiting plate and its associating intercalated ductules. The ductules observed in the present study revealed unexpectedly multiple connections with bile capillaries on their courses along the limiting plate as well as at the ends of their branches.

The anastomosing courses and the multiple connections with the bile capillary network are believed to elevate the tolerance of the intercalated portions to luminal obstruction. It has been established that bile contains various lipids and salts hardly soluble in water, and that some of its constituents tend to precipitate even in a physiological state (HOFMANN, 1989). It is worthy to note that fine bile ductules and limiting plates are sensitively altered by inflammation or fibrosis in the liver (ELIAS and SHERRICK, 1969).

At the junctions between the limiting plate and the intercalated ductules, some biliary lumina observed by SEM made an extreme approach toward the base of the ductular cells. These places may provide a potential route for the leakage of bile in case of biliary obstruction. MотTA et al. (1978) and MоттA (1984) regarded the portion where a bile capillary extended close to the perisinusoidal space of Disse as a locus minoris resistentiae for bile regurgitation to blood.

CLARA (1930) described ductular epithelial cells, which could be identified by their clear cytoplasm, as occurring in the hepatic lobule. He regarded the cells as "Endzellen (terminal cells)" of intercalted ductules which entered the lobules. The present SEM observation confirmed the existence of these cells, and further revealed numerous solitary ductular cells dispersed in the lobule. The presence of those solitary duclar cells might explain complex images of ductular cell proliferation, which have been recorded in various pathological states (STEINER and CARRUTHERS, 1963).

The present study is the first to demonstrate the plexus of biliary intercalated ductules and its relation to the limiting plate by a direct method, refuting the general assumption that the intercalated ductule is a short simple canal. The findings obtained by the present SEM observation will provide basic data for our understanding of the physiological and pathological roles of the intercalated portion in the biliary system.

Acknowledgments. The authors wish to thank Mr. Kazuo ADACHI for his excellent assistance in operating the scanning electron microscope.

\section{REFERENCES}

Bargmann, W.: Histologie und mikroskopische Anatomie des Menschen. 4th ed. Georg Thieme, Stuttgart, 1962 (p. 491-510).

ClaRA, M.: Untersuchungen an der menschlichen Leber. I. Über den Übergang der Gallenkapillaren in die Gallengänge. Z. Mikrosk. Anat. Forsch. 20: 584-607 (1930). 
Elias, H.: A re-examination of the structure of the mammalian liver. II. The hepatic lobule and its relation to the vascular and biliary systems. Amer. J. Anat. 85: 379-456 (1949).

Elias, H. and J. C. Sherrick: Morphology of the liver. Academic Press, New York-London, 1969.

Erlinger, S. and D. Dhumeaux : Mechanisms and control of secretion of bile water and electrolytes. Gastroenterology 66: 281-304 (1974).

Evan, A. P., W. G. Dail, D. Dammrose and C. Palmer: Scanning electron microscopy of cell surfaces following removal of extracellular material. Anat. Rec. 185: 433445 (1976).

Fujita, H. and T. FuJita: Textbook of histology, part 2 (In Japanese). 2nd ed. Igaku-Shoin Ltd., Tokyo, 1984 (p. 139-157).

Ham, A. W. and T. S. Leeson: Histology. 4th ed. J. B. Lippincott, Philadelphia-Montreal, 1961 (p. 637-655).

Hering, E.: Über den Bau der Wirbelthierleber. Arch. Mikrosk. Anat. 3: 88-114 (1867).

Hofmann, A. F.: Overview of bile secretion. In: (ed. by) J. G. ForTe: Handbook of physiology. Section 6: The gastrointestinal system, Vol. 3. American Physiological Association, Bethesda, 1989 (p. 549-566).

Jones, A. L. and E. SPring-Mills: The liver and gallbladder. In: (ed. by) L. WeIss: Cell and tissue biology. A textbook of histology. 6th ed. Urban \& Schwarzenberg, Baltimore-Munich, 1988 (p. 685-714).

KaYe, G. I., H. O. WheEler, R. T. Whitlock and N. LANE: Fluid transport in the rabbit gallbladder. A combined physiological and electron microscopic study. J. Cell Biol. 30: 237-268 (1966).

LETUlLe, M.: Les capillicules biliaires du foie humain, leur répartition à l'intérieur du lobule hépatique, leurs modes d'abouchement dans les canaux péri-lobulaires. J. Physiol. Pathol. Gén. 16: 789-801 (1915).

Maximow, A. A. and W. Bloom: A textbook of histology. 2nd. ed. W. B. Saunders, Philadelphia-London, 1935 (p. 412-428).

McIndoe, A. H.: The structure and arrangement of the bile canaliculi. Arch. Pathol. 6: 598-614 (1928).

MotTa, P. M.: The three-dimensional microanatomy of the liver. Arch. Histol. Jap. 47: 1-30 (1984).

Motta, P. M., M. Muto and T. Fusita: The liver. An atlas of scanning electron microscopy. Igaku-Shoin, Ltd., Tokyo, 1978.

MuRAKami, T.: A revised tannin-osmium method for non-coated scanning electron microscope specimens. Arch. Histol. Jap. 36: 189-193 (1974).

Murakami, T., T. Itoshima, K. Hitomi, A. OHtsuka and A. L. Jones: A monomeric methyl and hydroxypropyl methacrylate injection medium and its utility in casting blood capillaries and liver bile canaliculi for scanning electron microscopy. Arch. Histol. Jap. 47: 223-237 (1984).
Prenant, A. and P. Bouin: Traité d'histologie II. 1911. Cited in M. Clara (1930).

Smith, P. E. and W. M. Copenhaver: Bayley's text-book of histology. 12th ed. Williams \& Wilkins, Baltimore, 1948 (p. 479-490).

Steiner, J. W. and J. S. Carruthers: Studies on the fine structure of the terminal branches of the biliary tree. I. The morphology of normal bile canaliculi, bile preductules (ducts of Hering) and bile ductules. Amer. J. Pathol. 38: 639-661 (1961).

- Electron microscopy of hyperplastic ductular cells in $\alpha$-naphthyl isothiocyanate-induced cirrhosis. Lab. Invest. 12: 471-498 (1963).

STERnLIEB, I.: Functional implications of human portal and bile ductular ultrastructure. Gastroenterology 63 : 321-327 (1972).

StöHr, P., W. von MöllendorfF and K. GoertTer: Lehrbuch der Histologie und der mikroskopischen Anatomie des Menschen. 28th ed. VEB Gustav Fischer, Jena, 1959 (p. 319-331).

Takahashi-Iwanaga, H. and T. Fujita: Application of an $\mathrm{NaOH}$ maceration method to a scanning electron microscopic observation of Ito cells in the rat liver. Arch. Histol. Jap. 49: 349-357 (1986).

YAMADA, E.: The fine structure of the gall bladder epithelium of the mouse. J. Biophys. Biochem. Cytol. 1: 445458 (1955).

WallrafF, J.: Gallengangsystem, Gallenblase und Galle. In: Möllendorff's Handbuch der mikroskopischen Anatomie des Menschen, V/4. Springer, Berlin-HeidelbergNew York, 1969 (p. 277-292).

Williams, P. L. and R. WARWick: Gray's anatomy. 36th ed. Churchill Livingstone, Edinburgh-London-MelbourneNew York, 1980 (p. 1374-1382).

Zimmermann, K. W.: Die Speicheldrüsen der Mundhöhle und die Bauchspeicheldrüse. In: Möllendorff's Handbuch der mikroskopischen Anatomie des Menschen, V/ 1. Springer, Berin-Heidelberg-New York, 1927 (p. 61244).

Dr. Hiromi TAKaHASHI-IWANAGA

Department of Anatomy

Niigata University School of Medicine Asahimachi, Niigata

951 Japan

岩永ひろみ

951 新潟市旭町通 1

新潟大学医学部

第三解剖学教室 